\title{
Extracellular proteases of Halobacillus blutaparonensis strain M9, a new moderately halophilic bacterium
}

\author{
Anderson F. Santos ${ }^{1,2}$, Roberta S. Valle ${ }^{1}$, Clarissa A. Pacheco ${ }^{1,3}$, Vanessa M. Alvarez ${ }^{1}$, \\ Lucy Seldin ${ }^{1}$, André L.S. Santos ${ }^{1,2}$ \\ ${ }^{1}$ Departamento de Microbiologia Geral, Instituto de Microbiologia Paulo de Góes, Centro de Ciências da \\ Saúde, Universidade Federal do Rio de Janeiro, Rio de Janeiro, RJ, Brazil. \\ ${ }^{2}$ Programa de Pós-Graduação em Bioquímica, Instituto de Química, Universidade Federal do Rio de \\ Janeiro, Rio de Janeiro, RJ, Brazil. \\ ${ }^{3}$ Instituto Federal de Educação, Ciência e Tecnologia do Rio de Janeiro, Rio de Janeiro, RJ, Brazil.
}

Submitted: May 14, 2012; Approved: April 4, 2013.

\begin{abstract}
Halophilic microorganisms are source of potential hydrolytic enzymes to be used in industrial and/or biotechnological processes. In the present study, we have investigated the ability of the moderately halophilic bacterium Halobacillus blutaparonensis (strain M9), a novel species described by our group, to release proteolytic enzymes. This bacterial strain abundantly proliferated in Luria-Bertani broth supplemented with $2.5 \% \mathrm{NaCl}$ as well as secreted proteases to the extracellular environment. The production of proteases occurred in bacterial cells grown under different concentration of salt, ranging from $0.5 \%$ to $10 \% \mathrm{NaCl}$, in a similar way. The proteases secreted by $H$. blutaparonensis presented the following properties: (i) molecular masses ranging from 30 to $80 \mathrm{kDa}$, (ii) better hydrolytic activities under neutral-alkaline $\mathrm{pH}$ range, (iii) expression modulated according to the culture age, (iv) susceptibility to phenylmethylsulphonyl fluoride, classifying them as serine-type proteases, (v) specific cleavage over the chymotrypsin substrate, and (vi) enzymatic stability in the presence of salt (up to $20 \% \mathrm{NaCl}$ ) and organic solvents (e.g., ether, isooctane and cyclohexane). The proteases described herein are promising for industrial practices due to its haloalkaline properties.
\end{abstract}

Key words: Halobacillus blutaparonensis, halophilic bacterium, serine proteases.

\section{Introduction}

Proteases are omnipresent, being found in a wide diversity of sources such as plants, animals and microorganisms. Microbial proteases are the most important industrial enzymes accounting for around $60 \%$ of the total enzyme market and they represent approximately $40 \%$ of the total enzyme production in the world ( $\mathrm{Ng}$ and Kenealy, 1986; Rao et al., 1998; Horikoshi, 1999; Gupta et al., 2002). Proteases can be classified as acid, neutral and alkaline, based on their optimal hydrolytic activity $\mathrm{pH}$ range. Among those proteases, the alkaline ones are particularly relevant due to their activity and stability in high $\mathrm{pH}$ value (Rao et al., 1998; Gupta et al., 1999, 2002a, 2002b) and, consequently, their wide biotechnological potential for industrial sectors such as laundry detergents, leather tanning, beer, food and pharmaceutical industry (Rao et al., 1998; Schallmey et al., 2004; Fujinami and Fujisawa, 2010). Currently, a great number of commercially available alkaline proteases originate from Bacillus strains (Rao et al., 1998; Gupta et al., 1999, 2002a, 2002b; Schallmey et al., 2004; Fujinami and Fujisawa, 2010).

Over the years, Bacillus species as well as Bacillus-related genera have emerged as promising extracellular protease producers (Schallmey et al., 2004; Fujinami and Fujisawa, 2010). Extracellular proteases from moderately halophilic microorganisms have been thoroughly identified and characterized, including in Bacillus clausii I-52 (Joo et

Send correspondence to A.L.S. Santos. Laboratório de Investigação de Peptidases, Departamento de Microbiologia Geral, Instituto de Microbiologia Paulo de Góes, Bloco E-subsolo, Sala 05, Centro de Ciências da Saúde, Universidade Federal do Rio de Janeiro, Av. Carlos Chagas Filho 373, $21941-902$ Cidade Universitária, Rio de Janeiro, RJ, Brazil. E-mail: andre@micro.ufrj.br, alsouzasantos@gmail.com. 
al., 2003), Bacillus subtilis FP-133 (Setyorini et al., 2006), Paenibacillus peoriae NRRL BD-62, Paenibacillus polymyxa SCE2 (Alvarez et al., 2006), Halobacillus sp. SR5-3 (Namwong et al., 2006), Halobacterium sp. SP1(1) (Akolkar et al., 2008), Virgibacillus sp. SK37 (Phrommao et al., 2011) and Geomicrobium sp. EMB2 (Karan and Khare, 2011).

Our study focused on the identification of enzymes produced by a new bacterium species belonging to the Halobacillus genus, which shows the following characteristics: moderately halophilic, Gram-positive, spore-forming, motile, strictly aerobic with rod cells and capability to grow in the absence or in the presence of $\mathrm{NaCl}$. This species was named Halobacillus blutaparonensis since it was isolated from the roots of Blutaparon portulacoides (Barbosa et al., 2006) that is a coastal perennial rhizomatous herb found on the sand strip parallel to the Restinga of Jurubatiba located in the north of Rio de Janeiro State, Brazil, which is an extremely preserved area comprising a strip of sand of $44 \mathrm{~km}$ in length. The plant $B$. portulacoides can endure the salinity stress, high temperatures and tide shift exposure characteristic of the area (Bernardi and Seeliger, 1989). In addition, it is of great medical interest due to the presence of flavonoids, irisone B, sitosterol, vanillic acid, as well as stigmasterol, sitosterol and campesterol steroids (Ferreira and Dias, 2000). Hence, exploring the potential bacteria that are associated to this plant can be a promising source of bioactive compounds. With this task in mind, we have aimed to identify the proteases secreted by the new bacterial species $H$. blutaparonensis strain M9.

\section{Materials and Methods}

\section{Microorganism and culture conditions}

The strain M9 of Halobacillus blutaparonensis, originally described by Barbosa et al. (2006), was cultivated in Luria-Bertani (LB) broth that contains in its formulation $0.5 \% \mathrm{NaCl}$. Cells were incubated without agitation at $32{ }^{\circ} \mathrm{C}$ for $48 \mathrm{~h}$. Working cultures were kept on LB agar plates at $4{ }^{\circ} \mathrm{C}$, while long-term storage was followed in LB slants supplemented with $1 \% \mathrm{CaCO}_{3}$ (Seldin et al., 1983).

\section{Influence of salt on the bacterial growth}

Bacterial cells were incubated in LB broth supplemented with different concentrations of $\mathrm{NaCl}(0.5 \%, 2.5 \%$, $5.0 \%$ and $10.0 \%$ ) at $32{ }^{\circ} \mathrm{C}$ up to $96 \mathrm{~h}$. In order to evaluate the growth kinetics, an aliquot of each system was recovered every $24 \mathrm{~h}$, diluted $\left(10^{-3}\right.$ to $\left.10^{-6}\right)$ and then plated onto LB solid medium containing the respective $\mathrm{NaCl}$ concentration. Afterwards, all the plates were incubated for $48 \mathrm{~h}$ to count the colony-forming units (CFU).

\section{Influence of salt on the production of proteolytic enzymes}

Determination of protease production was primarily performed by using LB agar plates (containing $0.5 \%, 2.5 \%$,
$5.0 \%$ and $10.0 \% \mathrm{NaCl}$ ) supplemented with $0.4 \%$ gelatin (Sigma-Aldrich Chemical Co., USA). Briefly, ten microliters of the bacterial suspension were placed in the center of agar plates (9-cm diameter Petri dishes) and then incubated at $32{ }^{\circ} \mathrm{C}$ for $24,48,72$ and $96 \mathrm{~h}$. The gelatin degradation was revealed by flooding the plates with a solution containing $15 \%(\mathrm{w} / \mathrm{v})$ mercuric chloride in $20 \% \mathrm{HCl}$. After $10 \mathrm{~min}$, a clear transparent zone indicated hydrolysis of the gelatin by extracellular proteolytic activity, whereas the rest of the plate became opaque because of the coagulation of gelatin by $\mathrm{HgCl}_{2}$ (Fraziern, 1926). The colony diameter (a) and the diameter of colony plus the clear zone (b) were measured by a digital paquimeter. The enzymatic index (EI) was expressed as follows: $\mathrm{EI}=\mathrm{b} / \mathrm{a}$. The EI value of three different samples was measured to obtain the average value.

\section{Cell-free culture supernatants}

H. blutaparonensis cultures $(200 \mathrm{~mL})$ were centrifuged $\left(15.000 \mathrm{~g} / 20 \mathrm{~min} / 4^{\circ} \mathrm{C}\right)$ and the supernatants were filtered through a $0.22-\mu \mathrm{m}$ membrane (Millipore). The cell-free culture supernatants were concentrated 50 -fold using a 10,000 molecular weight cut-off Amicon micropartition system (Stirred Cell Model 8200) (Alvarez et al., 2006). Protein concentration was determined by the method described by Lowry et al. (1951), using bovine serum albumin (BSA) as standard.

\section{Zymography}

Proteases were assayed and partial characterized by $10 \%$ sodium dodecyl sulfate-polyacrylamide gel electrophoresis (SDS-PAGE) with $0.1 \%$ co-polymerized gelatin as substrate (Heussen and Dowdle, 1980). Gels were loaded with $50 \mu \mathrm{g}$ of protein per slot. After electrophoresis, at a constant current of $120 \mathrm{~V}$ at $4{ }^{\circ} \mathrm{C}$, SDS was removed by incubation with 10 volumes of $2.5 \%$ Triton X-100 for $1 \mathrm{~h}$ at room temperature under constant agitation. In order to promote the proteolysis, the gels were incubated for $48 \mathrm{~h}$ at 37 ${ }^{\circ} \mathrm{C}$ in the following buffer systems: $20 \mathrm{mM}$ sodium phosphate buffer (pH 5.0 and 7.0) and $20 \mathrm{mM}$ glycine- $\mathrm{NaOH}$ (pH 9.0) in the absence or in the presence of proteolytic inhibitors (Sigma) (10 mM phenylmethylsulphonyl fluoride (PMSF), $10 \mathrm{mM}$ 1,10-phenanthroline, $10 \mathrm{mM}$ ethylenediaminetetraacetic acid (EDTA), $10 \mu \mathrm{M}$ trans-epoxysuccinyl L-leucylamido-(4-guanidino) butane (E-64) and $10 \mu \mathrm{M}$ pepstatin A). The gels were stained for $2 \mathrm{~h}$ with $0.2 \%$ Coomassie brilliant blue R-250 in methanol:acetic acid:water $(50: 10: 40)$ and destained overnight in a solution containing methanol:acetic acid:water (5:10:85), to intensify the digestion halos. The molecular masses of the proteases were calculated by comparison with the mobility of low molecular mass standards. The gels were dried, scanned and digitally processed (Alvarez et al., 2006). The quantification of proteolytic halos was performed by densito- 
metrical analyzes using the public domain Image $\mathrm{J}$ software.

\section{Cleavage of chromogenic peptide substrates}

The crude supernatant fluid of $H$. blutaparonensis was test to cleave the following chromogenic substrates (Sigma): $N$-Succinyl-Ala-Ala-Ala- $p$-nitroanilide (elastase substrate), $\quad N$-Succinyl-Ala-Ala-Pro-Phe $\quad p$-nitroanilide (chymotrypsin substrate) and $N$-Benzoyl-Phe-Val-Arg- $p$ nitroanilide (trypsin substrate). The reactions were started by the addition of each substrate at $1 \mathrm{mM}$ to the supernatant fluid $(50 \mu \mathrm{g})$ diluted in $20 \mathrm{mM}$ glycine- $\mathrm{NaOH}, \mathrm{pH} 9.0$. The reaction mixtures were incubated at $37^{\circ} \mathrm{C}$ up to $120 \mathrm{~min}$ and the rate of substrate hydrolyses (the formation of $p$ nitroaniline) were determined by Thermomax Molecular Device microplate reader at $405 \mathrm{~nm}$. A control for each chromogenic substrate, where the substrate was added just after the reactions were stopped, was used as blank. One unit of proteolytic activity was defined as the amount of enzyme that caused an increase of 0.001 in absorbance unit, under standard assay conditions.

\section{Effects of salt and organic solvents on protease activity}

The stability of the crude proteases was also investigated in the presence of various organic solvents (at 25\% $\mathrm{v} / \mathrm{v}$ ) and salt concentrations (up to $20 \% \mathrm{NaCl}$ ). The reaction mixtures and the rate of substrate hydrolyses were determined as described above.

\section{Statistical analysis}

The experiments were performed in triplicate, in three independent experimental sets. The data were analyzed statistically by means of Student's $t$-test using EPI-INFO 6.04 (Database and Statistics Program for Public Health) computer software. P values of 0.05 or less were considered statistically significant.

\section{Results and Discussion}

Figure 1 shows the growth curves of H. blutaparonensis when cultivated at $32^{\circ} \mathrm{C}$ for a period of 1 to 4 days in LB broth supplemented with different salt concentrations. This bacterial species attained the log phase after $24 \mathrm{~h}$ of cultivation in $\mathrm{LB}$ added with $\mathrm{NaCl}$ at either $2.5 \%$ or $5.0 \%$, and by the second day in LB added with $0.5 \% \mathrm{NaCl}$. Elevated amount of $\mathrm{NaCl}(10.0 \%)$ retarded the bacterial proliferation. Moreover, they differed in growth pattern, which revealed a poor growth of $H$. blutaparonensis in LB medium containing $0.5 \%, 5.0 \%$ or $10.0 \% \mathrm{NaCl}$ and an abundant proliferation when LB plus $2.5 \% \mathrm{NaCl}$ was used (Figure 1, inset).

To adapt to saline conditions, bacteria have developed various strategies to maintain cell structure and function. Studies of such bacteria are of great importance, as

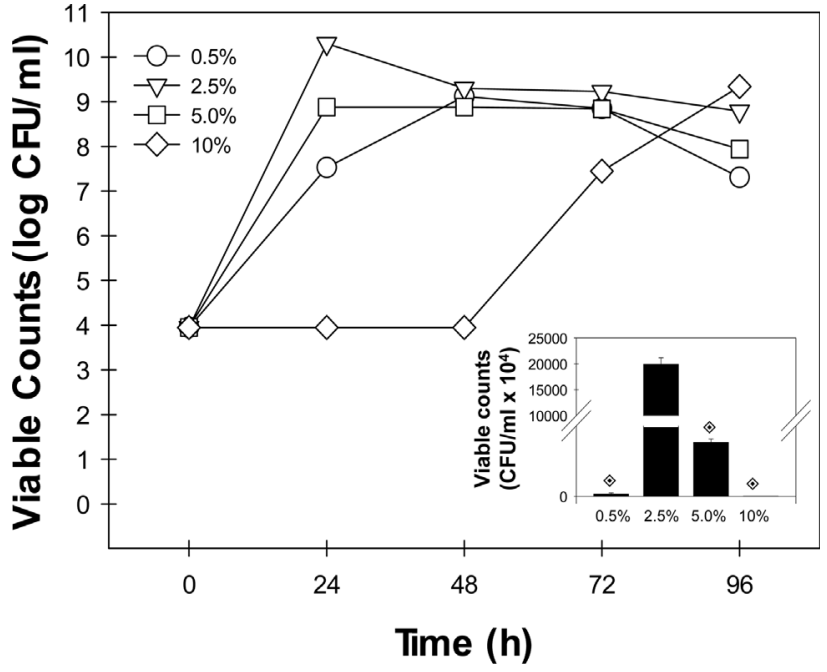

Figure 1 - Growth curve profiles of H. blutaparonensis cultured in LB medium supplemented with different concentrations of $\mathrm{NaCl}(0.5 \%, 2.5 \%$, $5.0 \%$ and $10.0 \%$ ) at $32{ }^{\circ} \mathrm{C}$ up to $96 \mathrm{~h}$. The inset emphasizes the difference among the abundant bacterial proliferation in the presence of $2.5 \% \mathrm{NaCl}$ when compared to the other systems after $24 \mathrm{~h}$ of in vitro growth. The values represent the mean of three independent experiments performed in triplicate. $P$ values of 0.05 or less were considered statistically significant $(\diamond$, Student's t-test).

they may produce compounds of industrial interest, such as extracellular hydrolytic enzymes that have diverse potential usage in biomedical science and chemical industries (Ventosa and Nieto, 1995; Margesin and Schinner, 2001; Mellado and Ventosa, 2003). Proteases are the largest selling industrial enzymes. Their sale is projected to increase further in the coming years with anticipated applications in protein processing, peptide synthesis and detergent formulations. However, the above-mentioned applications necessitate the proteases to be stable in salts, organic solvents and alkaline $\mathrm{pH}$, respectively (Gupta et al., 1999, 2002a, $2002 b$ ). In this context, halotolerant and/or halophilic microorganisms are valuable source of novel enzymes, including proteases, for using in different industrial practices. Taking this finding in mind, the production of proteases by H. blutaparonensis was initially investigated onto LB agar plates supplemented with both $\mathrm{NaCl}$ and gelatin during a period of $96 \mathrm{~h}$ of growth (Figure 2). The gelatin degradation was observed in bacterial cells grown under different concentration of salt, ranging from $0.5 \%$ to $10 \% \mathrm{NaCl}$, in a similar way (Figure 2). As it is well-known, the stability and activity of the enzyme in the presence and absence of salt make it quite interesting for wider applications in biotechnological processes (Rao et al., 1998; Gupta et al., 1999, 2002a, 2002b).

After these first results, LB broth supplemented with $2.5 \% \mathrm{NaCl}$ was chosen to carry out the further experiments. In this context, the secretion of proteolytic enzymes was examined in the culture supernatants of $H$. blutaparonensis along $96 \mathrm{~h}$ of in vitro growth. A simple inspection of the overlay gels showed that the secreted proteases were more 


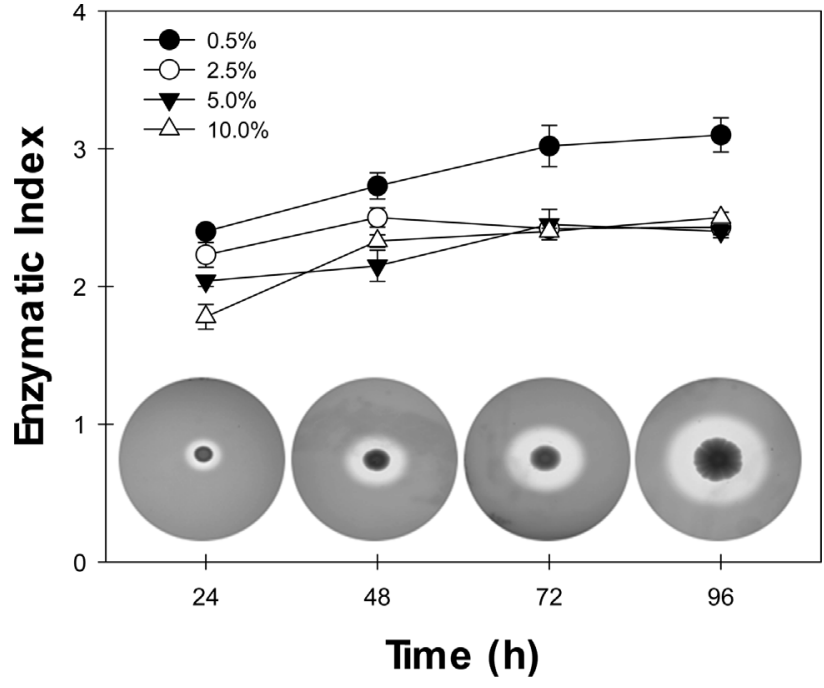

Figure 2 - Protease production by H. blutaparonensis cultured in LB solid medium supplemented with different concentrations of $\mathrm{NaCl}(0.5 \%, 2.5 \%$, $5.0 \%$ and $10.0 \%$ ) at $32{ }^{\circ} \mathrm{C}$ up to $96 \mathrm{~h}$. The enzymatic index was expressed as the ratio of colony diameter and the diameter of colony plus the clear zone. The values represent the mean \pm standard error of three independent experiments performed in triplicate. The inset exemplifies a representative image of the results, showing the gelatin degradation in LB medium added of $0.5 \% \mathrm{NaCl}$.

active under neutral-alkaline $\mathrm{pH}$ range (Figure 3). At least five major proteolytic bands were observed with molecular masses ranging from 80 to $30 \mathrm{kDa}$. We also observed that different proteolytic expression by $H$. blutaparonensis was induced depending on culture age: proteases of $80,70,55$ and $50 \mathrm{kDa}$ were more pronounced in culture supernatant harvested after two days of cultivation (stationary phase) at neutral $\mathrm{pH}$, while the $30 \mathrm{kDa}$ protease had its production enhanced along the $96 \mathrm{~h}$ of growth with noticeable activity at alkaline $\mathrm{pH}$ (Figure 3). Similarly, maximum protease production in stationary phase is well documented in Pseudoalteromonas sp. strain CP76 (Sanchez-Porro et al., 2003) and Bacillus sphaericus (Singh et al., 2004).

Aiming to characterize these proteases more fully, we tested their activities in gelatin-containing gels in the presence of proteolytic inhibitors. The results showed that the extracellular proteolytic profile of $H$. blutaparonensis was composed exclusively by serine-type proteases, displaying total sensibility to PMSF (Figure 4). Conversely, 1,10phenanthroline (a zinc metalloprotease inhibitor), E-64 (a cysteine protease inhibitor) and pepstatin A (an aspartic protease inhibitor) did not significantly interfere with the secreted proteolytic activities (Figure 4). Interestingly, EDTA (a calcium metalloprotease inhibitor/chelating agent) partially inhibited the proteases released by $H$. blutaparonensis (Figure 4). Likewise, Karbalaei-Heidari et al. (2009) purified a $36 \mathrm{kDa}$ alkaline extracellular protease from Halobacillus karajensis strain MA-2 sensible to classical serine protease inhibitors (PMSF and Pefabloc SC) and EDTA, indicating that it probably belongs to the subclass of

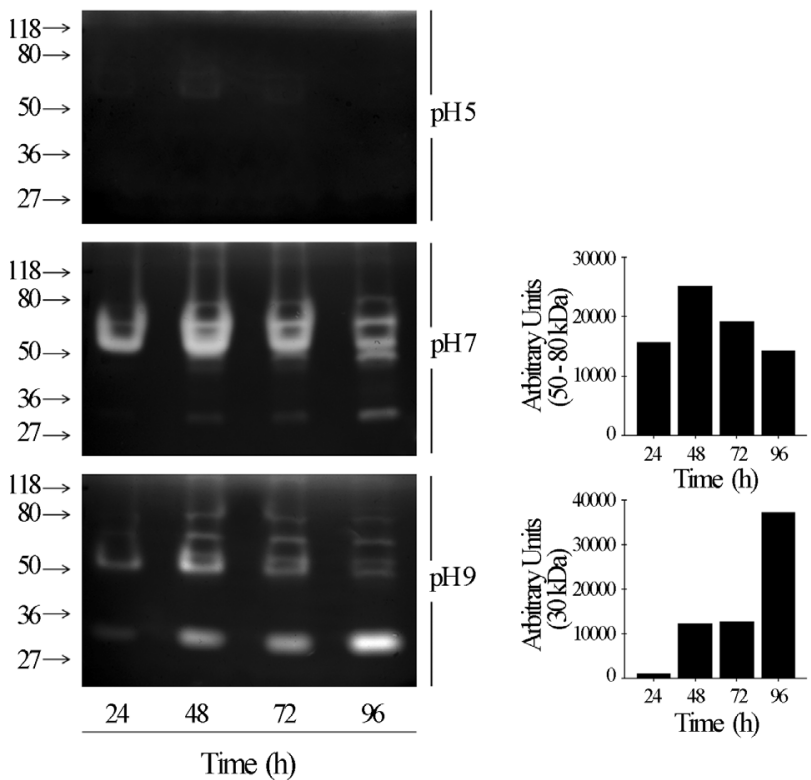

Figure 3 - Effect of $\mathrm{pH}$ and culture age on the extracellular protease profile of $H$. blutaparonensis cultured in LB medium supplemented with $2.5 \% \mathrm{NaCl}$ at $32{ }^{\circ} \mathrm{C}$. Proteolytic profiles were evidenced by gelatin-SDS-PAGE. The gel strips were incubated in different buffer systems: $20 \mathrm{mM}$ sodium phosphate buffer ( $\mathrm{pH} 5$ and 7) and $20 \mathrm{mM}$ glycine- $\mathrm{NaOH}$ ( $\mathrm{pH}$ 9). The numbers on the left indicate the apparent molecular masses of protein standards, expressed in kilodaltons. The graphics on the right represents the densitometric analyses of the proteolytic halos, expressed in arbitrary units of proteolytic activity.

serine metalloproteases. This inhibition profile is commonly observed in many members of the subtilase superfamily, including subtilisins, which are one of the most valuable industrial enzymes and have been extensively studied in terms of molecular structure, protein engineering and their application (Rao et al., 1998; Gupta et al., 2002a). Gram-positive bacilli are well-known sources for high productivity of subtilisins (Sanchez-Porro et al., 2003).

The degradation of different serine protease substrates was employed using the supernatant fluid of $H$.
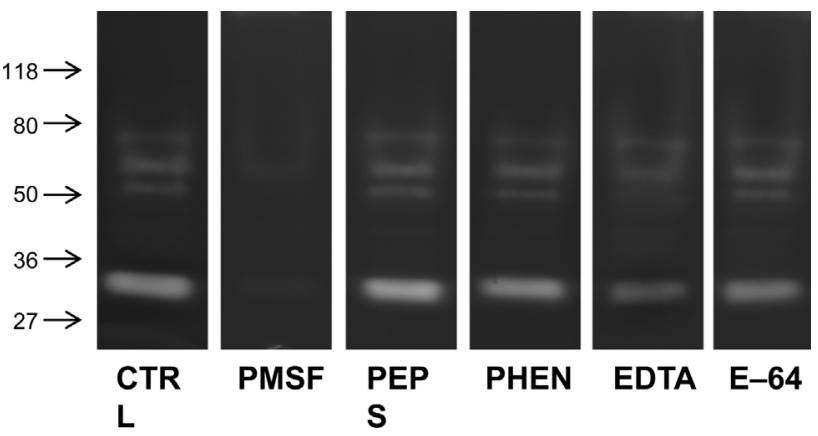

Figure 4 - Effect of proteolytic inhibitors on the proteases secreted by $H$. blutaparonensis. The gel strips, containing the supernatant of cells cultured in $\mathrm{LB}$ medium added of $2.5 \% \mathrm{NaCl}$ for $96 \mathrm{~h}$, were incubated in $20 \mathrm{mM}$ glycine- $\mathrm{NaOH}(\mathrm{pH} 9)$ in the absence (CTRL) or in the presence of the following inhibitors: $10 \mathrm{mM}$ PMSF, $10 \mu \mathrm{M}$ pepstatin A (PEPS), $10 \mathrm{mM}$ 1,10-phenanthroline (PHEN), $10 \mathrm{mM}$ EDTA and $10 \mu \mathrm{M} \mathrm{E}-64$. The numbers on the left indicate the apparent molecular masses of protein standards, expressed in kilodaltons. 
blutaparonensis (Figure 5). To this end, we performed kinetic assays using chromogenic peptide substrates specific to elastase, trypsin and chymotrypsin. The serine proteases secreted by $H$. blutaparonensis showed elevated degradation rate on the chymotrypsin substrate when compared to trypsin or elastase substrates (Figure 5). As expected, PMSF was able to completely abolish the cleavage of the chromogenic chymotrypsin substrate (data not shown).

In industrial applications, use of crude enzyme is preferred over purified preparation. This is to avoid the cost of purification and make the processes commercially viable. The applications of crude proteases have been highlighted in several processes, for instance, the crude protease from the extreme halophilic archaea Halobacterium sp. SP1 (Akolkar et al., 2008) that is stable over a broad $\mathrm{pH}$ range and high salt concentration has been effectively used in order to accelerate the fish sauce fermentation process (Akolkar et al., 2010). Joshi et al. (2007) described the production of alkaline serine protease stable in the presence of $\mathrm{NaCl}$, SDS and acetone by a moderately halotolerant strain of Bacillus cereus (designated MTCC 6840) isolated from Lake Nainital, Uttaranchal State, India. Herein, the preliminary characterization of the crude proteases secreted by $H$. blutaparonensis was undertaken more specifically to assess the novel features of enzyme in terms of its catalytic behavior and stability in distinct organic solvents and different concentrations of salt (Figure 6). The proteases of $H$. blutaparonensis were highly stable in the presence of $\mathrm{NaCl}$ up to $20 \%$ along 60 min of experimentation (Figure 6A). Regarding the effects of organic solvents, the proteolytic activity showed high stability in ether, isooctane and cyclohexane (at 25\% v/v) after $60 \mathrm{~min}$ (Figure 6B); however,

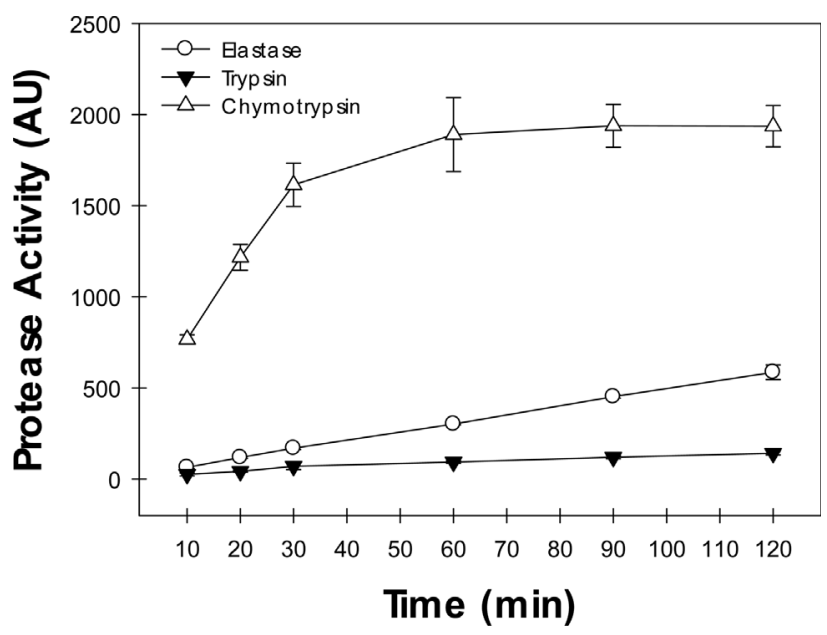

Figure 5 - Time course of hydrolysis of chromogenic substrates from serine proteases secreted by H. blutaparonensis. The chromogenic substrates used are specific to measure the proteolytic activity of elastase ( $N$-Succinyl-Ala-Ala-Ala- $p$-nitroanilide), trypsin ( $N$-Benzoyl-Phe-ValArg- $p$-nitroanilide) and chymotrypsin ( $N$-Succinyl-Ala-Ala-Pro-PhePhe-p-nitroanilide). The enzymatic activities, expressed in arbitrary units (AU), were determined at $37^{\circ} \mathrm{C}$ for 120 min under alkaline conditions of $\mathrm{pH}(\mathrm{pH}$ 9.0). The values represent the mean \pm standard error of three independent experiments performed in triplicate.

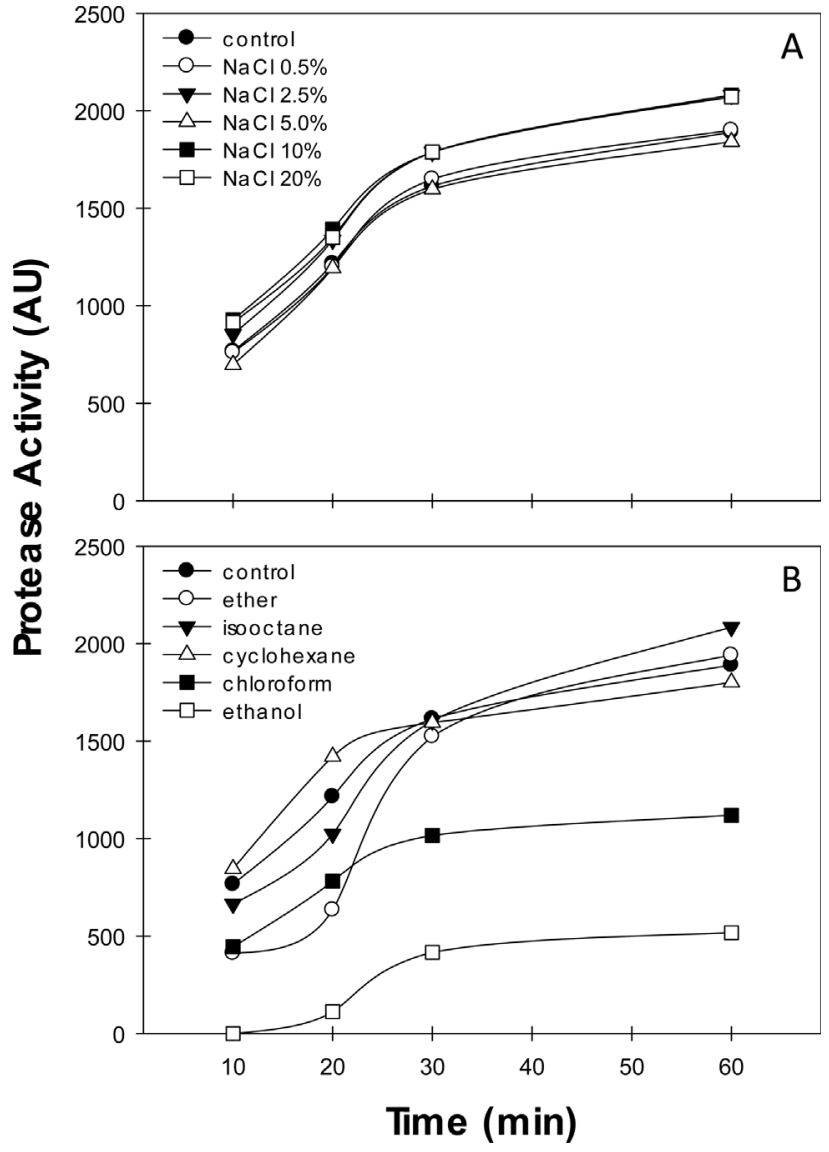

Figure 6 - Effect of salt concentration (A) and organic solvents (B) on the time course of hydrolysis of chymotrypsin chromogenic substrate from serine proteases secreted by H. blutaparonensis. The proteolytic activities were measured in the absence (control) or in the presence of different concentrations of $\mathrm{NaCl}(0.5,2.5,5,10$ and $20 \%)$ or organic solvents at $25 \% \mathrm{v} / \mathrm{v}$ (ether, isooctane, cyclohexane, chloroform and ethanol). The enzymatic activities, expressed in arbitrary units (AU), were determined at $37{ }^{\circ} \mathrm{C}$ for 60 min under alkaline conditions of $\mathrm{pH}(\mathrm{pH} 9.0)$. The values represent the mean of three independent experiments performed in triplicate.

chloroform and ethanol reduced the enzymatic activity around $40 \%$ and $70 \%$, respectively (Figure 6B).

In conclusion, this is the first study describing the protease production by the moderately halophilic bacterium $H$. blutaparonensis. Some of the features of the secreted proteases by this new bacterial species, such as production in the absence and presence of different salt concentrations, hydrolytic activity in a wide $\mathrm{pH}$ range (especially neutral-alkaline $\mathrm{pHs}$ ) and stability in salt and organic solvents are credentials to future biochemical studies. So, upcoming works are in progress in our laboratory in order to purify some of the extracellular proteases produced by $H$. blutaparonensis, aiming to test their application in some industrial/biotechnological processes.

\section{Acknowledgments}

This study was supported by grants from the Brazilian Agencies: Conselho Nacional de Desenvolvimento 
Científico e Tecnológico (CNPq), Fundação de Amparo à Pesquisa no Estado do Rio de Janeiro (FAPERJ), Coordenação de Aperfeiçoamento de Pessoal de Nível Superior (CAPES) and Conselho de Ensino e Pesquisa para Graduados da Universidade Federal do Rio de Janeiro (CEPGUFRJ). André L.S. Santos and Lucy Seldin are supported by CNPq and FAPERJ fellowships. Anderson F. Santos, a postgraduate student of Programa de Pós-Graduação em Bioquímica - Instituto de Química - Centro de Tecnologia UFRJ, is supported by a CAPES fellowship.

\section{References}

Akolkar AV, Deshpande GM, Raval KN, Durai D, Nerurkar AS, Desai AJ (2008) Organic solvent tolerance of Halobacterium sp. SP1(1) and its extracellular protease. J Basic Microbiol 48:1-5.

Akolkar AV, Durai D, Desai AJ (2010) Halobacterium sp. SP1(1) as a starter culture for accelerating fish sauce fermentation. $\mathrm{J}$ Appl Microbiol 109:44-53.

Alvarez VM, Von der Weid I, Seldin L, Santos ALS (2006) Influence of growth conditions on the production of extracellular proteolytic enzymes in Paenibacillus peoriae NRRL BD-62 and Paenibacillus polymyxa SCE2. Lett Appl Microbiol 43:625-630.

Barbosa DC, Von der Weid I, Vaisman N, Seldin L (2006) Halotolerant spore-forming Gram-positive bacterial diversity associated with Blutaparon portulacoides (St. Hill.) Mears, a pioneer species in Brazilian coastal dunes. J Microbiol Biotechnol 16:193-199.

Bernardi H, Seeliger U (1989) Population biology of Blutaparon portulacoides (St. Hill.) Mears on southern Brazilian backshores. Ciência \& Cultura 41:1110-1113.

Ferreira EO, Dias DAA (2000) Methylenedioxyflavonol from aerial parts of Blutaparon portulacoides. Phytochemistry 53:145-147.

Fraziern C (1926) A method for the detection of changes in gelatin due to bacteria. J Infect Dis 39:302-309.

Fujinami S, Fujisawa M (2010) Industrial applications of alkaliphiles and their enzymes - Past, present and future. Environ Technol 31:845-856.

Gupta R, Gupta K, Saxena RK, Khan S (1999) Bleach-stable, alkaline protease from Bacillus sp. Biotechnol Lett 21:135138.

Gupta R, Beg QK, Lorenz P (2002) Bacterial alkaline proteases: molecular approaches and industrial applications. Appl Microbiol Biotechnol 59:15-32.

Gupta R, Beg QK, Khan S, Chauhan B (2002) An overview on fermentation, downstream processing and properties of microbial alkaline proteases. Appl Microbiol Biotechnol 60:381-395.

Heussen C, Dowdle EB (1980) Electrophoretic analysis of plasminogen activators in polyacrylamide gels containing SDS and copolymerized substrates. Anal Biochem 102:196-202.

Horikoshi K (1999) Alkaliphiles: some applications of their products for biotechnology.Microbiol Mol Biol Rev 63:735-750.

Joo HS, Kumar CG, Park GC, Paik SR, Chang CS (2003) Oxidant and SDS-stable alkaline protease from Bacillus clausii I-52: production and some properties. J Appl Microbiol 95:267272.
Joshi GK, Kumar S, Sharma V (2007) Production of moderately halotolerant, SDS stable alkaline protease from Bacillus cereus MTCC 6840 isolated from Lake Nainital, Uttaranchal State, India. Braz J Microbiol 38:773-779.

Karan R, Khare SK (2011) Stability of haloalkaliphilic Geomicrobium sp. protease modulated by salt. Biochemistry (Mosc) 76:686-693.

Karbalaei-Heidari HR, Amoozegar MA, Hajighasemi M, Ziaee AA, Ventosa A (2009) Production, optimization and purification of a novel extracellular protease from the moderately halophilic bacterium Halobacillus karajensis. J Ind Microbiol Biotechnol 36:21-27.

Lowry OH, Rosebrough NJ, Farr AL, Randall RJ (1951) Protein measurement with the Folin phenol reagent. J Biol Chem 193:265-275.

Margesin R, Schinner R (2001) Potential of halotolerant and halophilic microorganisms for biotechnology. Extremophiles 5:73-83.

Mellado ME, Ventosa A (2003) Biotechnological potential of moderately and extremely halophilic microorganisms. In: Barredo JL (ed) Microorganisms for health care, food and enzyme production. Research Signpost, Kerala, p.233-256.

Namwong S, Hiraga K, Takada K, Tsunemi M, Tanasupawat S, Oda K (2006) A halophilic serine proteinase from Halobacillus sp. SR5-3 isolated from fish sauce: purification and characterization. Biosci Biotechnol Biochem 70:1395-1401.

Ng TK, Kenealy WR (1986) Industrial applications of thermostable enzymes. In: Brock, T.D. (Ed.), T.G.M. and Applied Microbiology. John Wiley, p.197-205.

Phrommao E, Rodtong S, Yongsawatdigul J (2011) Identification of novel halotolerant bacillopeptidase F-like proteinases from a moderately halophilic bacterium, Virgibacillus sp. SK37. J Appl Microbiol 110:191-201.

Rao MB, Tanksale AM, Ghatge MS, Deshpande VV (1998) Molecular and biotechnological aspects of microbial proteases. Microbiol Mol Biol Rev 62:597-635.

Rawlings ND, Morton FR, Kok CY, Kong J, Barrett AJ (2008) MEROPS: the peptidase database. Nucleic Acids Res 36:320-325.

Sanchez-Porro C, Mellado E, Bertoldo C, Antranikian G, Ventosa A (2003) Screening and characterization of the protease CP1 produced by the moderately halophilic bacterium Pseudoalteromonas sp. strain CP76. Extremophiles 7:221-228.

Schallmey M, Singh A, Ward OP (2004) Developments in the use of Bacillus species for industrial production. Can J Microbiol 50:1-17.

Seldin L, Van Elsas JD, Penido EGC (1983) Bacillus nitrogen fixers from Brazilian soils. Plant Soil 70:243-255.

Setyorini E, Takenaka S, Murakami S, Aoki K (2006) Purification and characterization of two novel halotolerant extracellular proteases from Bacillus subtilis strain FP-133. Biosci Biotech Biochem 70:433-440.

Singh J, Vohra RM, Sahoo DK (2004) Enhanced production of alkaline proteases by Bacillus sphaericus using fed-batch culture. Process Biochem 39:1093-1101.

Ventosa A, Nieto JJ (1995) Biotechnological applications and potentialities of halophilic microorganisms. World J Microbiol Biotechnol 11:85-94.

All the content of the journal, except where otherwise noted, is licensed under a Creative Commons License CC BY-NC. 